ISSN : $2302-1590$

E-ISSN: $2460-190 \mathrm{X}$

ECONOMICA

Journal of Economic and Economic Education Vol.4 No.2 (160 -176)

\title{
PEMBANGUNAN KORIDOR EKONOMI SUMATERA BARAT SEBAGAI STRATEGI MEMPERKUAT KONEKTIFITAS DENGAN PEREKONOMIAN NEGARA ASEAN
}

\author{
Ansofino \\ Program Studi Pendidikan Ekonomi, STKIP PGRI Sumatera Barat, \\ Jln Gunung Pangilun No: 1 Padang, Sumatera Barat, 25144 \\ Email: ansofino2001@yahoo.com \\ submited:2016.01.07 reviewed:2016.01.07 accepted: 2016.01.07 \\ http://dx.doi.org/10.22202/economica.2016.v4.i2.355
}

\begin{abstract}
The improvement of development economic zone through economic corridor begins with the development of primary commodities which have been increasing household income. It followed by the development of basic infrastructure through the development of regional logistic and local transportation system.Then it continued with the development of regional innovation system through value-added primary products enhancement on the economic corridor zone. Development of economic corridors zone will support acceleration of economic growth. It also supported by the development of connectivity within economic corridors in the province of West Sumatra. The development of the economic corridor connectivity is applied through development of regional logistic systems(Sislogda), the development of regional transport systems (sistrada) and the establishment of exsport processing zones its support to ASEAN economic community on 2015.
\end{abstract}

\begin{abstract}
Abstrak
Pengembangan zona pembangunan ekonomi melalui pembangunan koridor ekonomi dimulai dengan pengembangan komoditi utama yang selama ini mendorong pendapatan rumahtangga masyarakat, dilanjutkan dengan pengembangan infrastruktur dasar melalui pengembangan sistem logisitik daerah dan sistem trasportasi daerah, kemudian dilanjutkan dengan pengembangan peningkatan sistem inovasi daerah melalui peningkatan nilai tambah produk utama yang dihasilkan pada koridor ekonomi tersebut. Koridor ekonomi dengan tema pembangunan dan kegiatan ekonomi utamanya sebagai pemicu terjadinya percepatan pertumbuhan ekonomi, di dukung pula oleh strategi pengembangan konektifitas di dalam maupun antar koridor ekonomi yang ada di wilayah provinsi Sumatera Barat. Pengembangan konektifitas pada koridor ekonomi dilakukan melalui pengembangan sistem logistikdaerah (Sislogda) dan pengembangan sistem transportasi daerah (sistrada) dan pembentukan zona prosesing export, sebagai upaya menyambut pasar bebas ASEAN 2015.
\end{abstract}

Keywords : economic corridor, economic connectivity with ASEAN

(C2016 Prodi Pendidikan Ekonomi STKIP PGRI, Padang 


\section{PENDAHULUAN}

Proses pembangunan daerah Provinsi Sumatera Barat sudah dilakukan dalam periode waktu yang cukup lama, namun demikian hasil yang dapat dicapai ternyata masih jauh dari harapan. Hal ini terlihat dari penyediaan infrastruktur dan fasilitas pelayanan spasial yang masih terbatas serta tingkat kemakmuran dan kesejahteraan masyarakat yang masih relatif rendah jika dibandingkan dengan provinsi lain di Indonesia. Untuk dapat memperoleh hasil yang lebih baik, maka upaya pemerintah dalam mendorong proses pembangunan daerah perlu terus dilanjutkan dan ditingkatkan dengan memperhatikan kendala dan permasalahan yang terdapat di daerah dewasa ini. Disamping itu, dalam rangka mendorong percepatan pertumbuhan ekonomi Sumatera Barat telah pula disusun Master Plan Percepatan Perluasan Pembangunan Ekonomi Sumatera Barat (MP3ESB) untuk periode waktu 2012-2025. Lihat (Gubernur Provinsi Sumatera Barat, 2013).

Secara nasional telah terdapat Masterplan Percepatan dan Perluasan Pembangunan Ekonomi Indonesia (MP3EI) yang telah ditetapkan dengan Peraturan Presiden No: 32 Tahun 2011 tanggal 27 Mei 2011(Bappenas, 2011). Namun demikian, peranan Provinsi Sumatera Barat dalam rencana pembangunan ekonomi ini tidak terlihat dengan tegas. Karena itu, telah berhasil pula disusun MP3ESB dengan mengacu dan berpedoman pada MP3EI agar percepatan pembangunan ekonomi Sumatera Barat juga dapat dipercepat sehingga kemakmuran dan kesejahteraan masyarakat dapat terus ditingkatkan sebagaimana yang juga direncanakan pada tingkat nasional.

Percepatan pembangunan ekonomi daerah yang dilakukan melalui peningkatan pertumbuhan ekonomi dalam MP3ESB ini diwujudkan melalui 4 pandekatan analisis dan sistem penyusunan rencana, sebagai berikut:

(1) Peningkatan Nilai Tambah (Value Added) produksi barang dan jasa melalui kegiatan pengolahan dan distribusi produk-produk hasil pertanian, perkebunan, peternakan, perikanan dan pertambangan baik dalam bentuk barang setengah jadi (Intermediate Products) maupun barang yang siap di konsumsi (Final Products);

(2) Mewujudkan keterpaduan ekonomi sektoral dan spasial melalui pembentukan beberapa Kawasan Ekonomi Terpadu (KAPET), Kawasan Industri, Kawasan Sentra Produksi (KSP), Klaster Industri dan Pusat Pertumbuhan guna menciptakan Keuntungan Aglomerasi yang dapat menimbulkan daya tarik untuk melakukan investasi;

(3) Mendorong terwujudnya peningkatan efisiensi pemasaran serta integrasi pasar regional dan nasional serta domestik dan internasional dalam rangka meningkatkan daya saing dan daya tahan perekonomian daerah;

(4) Menunjang penguatan Sistem Informasi Daerah (SIDA) di bidang proses produksi guna meningkatkan kualitas produk serta penciptaan produk baru yang mempunyai nilai tinggi guna meningkatkan daya saing produk dalam era globalisasi dan otonomi daerah.

Tidak dapat disangkal bahwa keempat cara dan pendekatan analisis dan penyusunan rencana ini pada dasarnya saling terkait satu sama lainnya sehingga pelaksanaannya harus dilakukan secara terpadu dan berkelanjutan. Sedangkan aspek lokasi dan tata-ruang ditampilkan dalam bentuk peta sesuai dengan skala yang tersedia di daerah. 
Dalam dokumen MP3ESB terdapat tiga strategi utama yang dapat dilakukan untuk mempercepat pembangunan wilayah Sumatera Barat yakni:

1. Pengembangan potensi ekonomi melalui koridor ekonomi yang telah berhasil ditemukan yakni koridor ekonomi (KE) Pantai Barat, KE Lintas Timur dan KE Lintas Sumatera.

2. Penguatan konektifitas daerah melalui pembangunan dan pengembangan sistem logistic daerah (silogda) dan Sistem transportasi daerah (Sistrada)

3. Mempercepat kemampuan sumberdaya manusia dan IPTEKDA. Prasyarat yang harus dilakukan sebagai necessary condition agar ketiga strategi di atas dapat dicapai adalah:

1). Peningkatan nilai tambah produk barang dan jasa

2). Menciptakan agglomerasi ekonomi pemicu daya tarik investasi

3). Efisiensi pemasaran dan integrasi pasar regional, nasional dan internasional global

4). Produk baru yang berdaya saing

Inisiatif strategi yang dapat dilakukan agar terciptanya necessary condition diatas sehinga percepatan pembangunan ekonomi benar-benar dapat diwujudkan adalah dengan mendorong investasi BUMN dan BUMD, swasta daerah dan foreign direct investment (FDI) pada kegiatan ekonomi utama di setiap koridor ekonomi yang ada. Melakukan sinkronikasi rencana aksi daerah untuk revitalisasi kinerja sektoril yakni pembangunan jalan tol Padang - Bukittingi - Payakumbuh _ batas Riau, pembangunan jalan kereta api menuju bandara BIM, dan perluasan bandara BIM dan Pelabuahan teluk Bayur untuk melayani kegiatan kargo internasional.
Pengembangan centre excellent seperti academy communitas pada setiap koridor ekonomi untuk menjiapkan tenaga kerja terampil di bidang komoditi utama yang menjadi andalan setiap koridor. Inisiatif strategi ini menjadi sufficien condition untuk terwujudkan percepatan pembangunan ekonomi wilayah Sumatera Barat di masa depan.

Pokok persoalan yang dikaji dalam penelitian ini adalah:

1. Apakah wilayah Sumatera Barat telah memiliki pusat-pusat unggulan ekonomi dan klaster industri yang sesuai dengan potensi dan unggulan ekonomi koridor Sumatera?

2. Bagaimana konektifitas antara pusatpusat ekonomi dan klaster industri yang telah ada selama ini ? apakah cukup memadai untuk mendukung pengembangan koridor ekonomi Sumatera?

3. Bagaimana strategi utama dalam percepatan dan perluasan perekonomian Sumatera Barat 2012-2025 agar mampu mengambil bagian dari pengembangan koridor ekonomi Sumatera?

4. Bagaimana pengembangan koridor ekonomi Sumatera Barat yang mampu bersaing dengan koridor ekonomi provinsi tetangga untuk memperkuat konektifitas dengan koridor Sumatera ?

5. Bagaimana penguatan konektifitas wilayah Sumatera Barat, sinergi antara pusat-pusat ekonomi dengan jaringan infrastruktur daerah ? apakah konektifitas wilayah Sumatera Barat ini mampu terkoneksi dengan pusat-pusat ekonomi regional Sumatera?

Tujuan penelitian secara khusus
adalah untuk mensinergikan antara 
pengembangan perekonomian wilayah Sumatera Barat dengan pengembangan koridor ekonomi Sumatera yang dikembangkan dalam MP3EI oleh pemerintahan nasional. Sehingga wilayah Sumatera Barat sebagai bagian dari rencana pengembangan koridor ekonomi Sumatera dengan potensi dan unggulan yang berbasis pengolahan hasil bumi dan lumbung energy nasional, seperti karet, kelapa sawit, batubara, besi dan baja, dapat memanfaatkan rencana pengambangan koridor Sumatera ini, sehingga juga dapat menarik dan perekonomian Sumatera Barat sebagai bagian dari system perekonomian wilayah Sumatera, guna menghadapi dan memenangkan persaingan ekonomi global.

Metodologi penelitian yang digunakan adalah metode analisis ekonomi wilayah dengan beberapa peralatan analisisnya Location quotient (LQ), shift share analysis (SSA), analisis keterkaitan spatial dengan menggunakan geografical accessibility index, dan Accessibility potential matrix, dan terakhir analisis klaster potensi ekonomi. Data yang digunakan adalah data primer dan sekunder, pengumpulan data dilakukan dengan diskusi kelompok terarah (Focus Group Discussion).

\section{HASIL PENELITIAN DAN PEMBAHASAN}

\section{Koridor Ekonomi Sumatera Barat}

Setiap koridor ekonomi yang telah terbentuk di wilayah provinsi Sumatera Barat telah ditentukan tema pembangunannya yakni:

1. Koridor Ekonomi Lintas Sumatera (Padang- Padang Panjang- BukittinggiTanah Datar, 50 Kota, Pasaman Payakumbuh) tema pembangunan koridornya adalah sebagai pusat produksi industry dan jasa, pintu gerbang perdagangan dan jasa, wisata MICE dan alam

2. Koridor Ekonomi Lintas Timur (Padang- Solok - Sawahlunto Sijunjung dan Dharmasraya dan Solok Selatan tema pembangunan koridornya adalah pusat produksi pertanian perkebunan dan industry agro

3. Koridor Ekonomi Pantai Barat (Mentawai, Pessel, Pariaman, Padang Pariaman, Agam, Pasaman Barat tema pembangunan koridor ekonominya adalah pusat produksi dan pengolahan perikanan, perkebunan, energy dan pertambangan daerah.

Berdasarkan koridor ekonomi yang terbentuk dan telah diikuti dengan tema pembangunan pada setiap koridor ekonomi yang ada, maka dapat pula dikemukakan sebaran kegiatan utama berdasarkan koridor ekonomi yang ada, sebagaimana dapat dilihat pada gambar di bawah.

Koridor Lintas Sumatera sebagai koridor 1, kegiatan utamanya adalah aktifitas ekonomi industry seperti industry kimia dan bahan bangunan serta industry kerajinan, peternakan dan wisata MICE,. Pada koridor ekonomi Gerbang Timur sebagai koridor ekonomi 2, kegiatan utamanya adalah aktifitas ekonomi industry perkebunan, pertambangan dan wisata budaya. Pada koridor ekonomi Pantai Barat kegiatan utamanya adalah indutsri perikanan tangkap dan budidaya, pertambangan dan industry kreatif. Dengan demikian dengan strategi pengembangan koridor ekonomi berdasarkan potensi ekonomi yang dimiliki, maka percepatan pembangunan wilayah dapat dilakukan. 


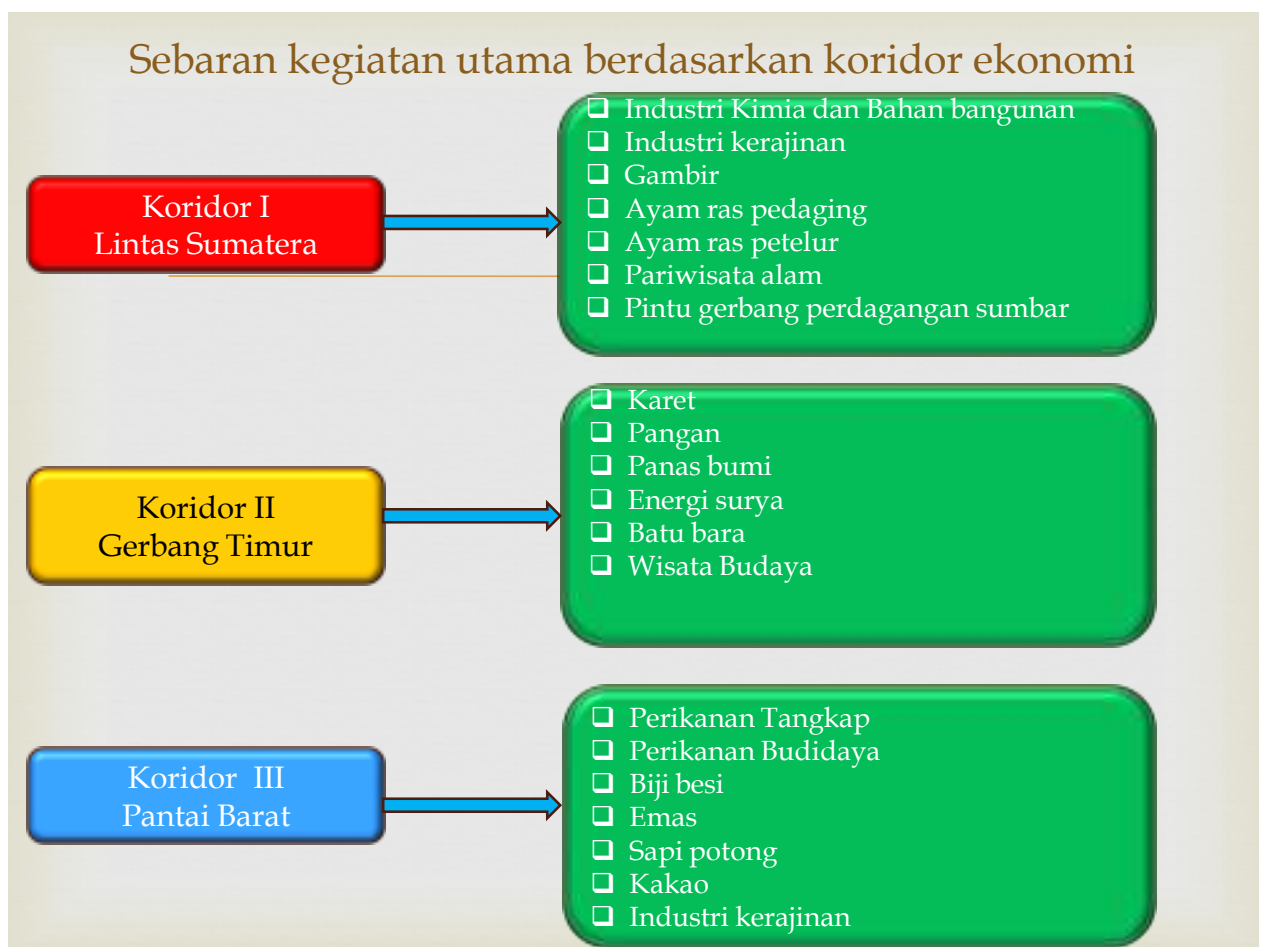

\section{Gambar 1: Sebaran Kegiatan Utama Berdasarkan Koridor Ekonomi}

Strategi kedua dalam MP3ESB itu adalah pengembangan konektifitas yang dapat dilakukan dengan beberapa langkah strategisnya yakni:

1. Membangun konektifitas daerah untuk mendorong pertumbuhan yang inklusif

2. Membuat keterpaduan secara local dan terhubung secara global (locally integrated, globally connected.

3. Mengembangkan sistem logistic daerah

4. Mengembangkan sistem transportasi daerah

5. Menghubungkan pusat-pusat pertumbuhan utama untuk mengoptimalkan pertumbuhan berdasarkan prinsip-prinsip keterpaduan
6. Memperluas pertumbuhan dengan menghubungkan daerah tertinggal/pheri-pheri dengan pusat pertumbuhan

7. Menghubungkan daerah hinterland dengan infrastruktur dan pelayanan dasar dalam menyebarkan manfaat ekonomi pembangunan secara luas.

Strategi ketiga dalam MP3ESB adalah pengembangan SDM dan IPTEKDA untuk mendukung percepatan pertumbuhan ekonomi yang didorong oleh innovation driven. Langkah strategisnya adalah sebagai berikut:

1. Pengembangan Klaster Inovasi untuk Mendukung 3 (koridor) Ekonomi. Pengembangan centre of 
excellence yang terintegrasi dengan klaster-klaster industri.

2. Revitalisasi kelembagaan IPTEK sebagai Sain \& Techno Park

3. Pembentukan Klaster Inovasi Daerah untuk pemerataan pertumbuhan mendorong dan memberdayakan upaya masyarakat, pelaku usaha, pemerintah daerah, untuk menumbuhkembangkan potensi inovasi pada beberapa produk dan program unggulan wilayah setiap koridor ekonomi.

\section{Konsep Pengembangan Investasi}

Apakah yang dilihat sebagai pendekatan yang sangat pratis dalam pembangunan ekonomi suatu wilayah adalah melakukan investasi untuk memperbaiki pertanian, berinvestasi untuk memperbaiki infrastruktur dan berinvestasi untuk memperbaiki kesehatan dan pendidikan dasar. Dengan berinvestasi pada tiga sector ini, bukan hanya akan meningkatkan kualitas hidup tetapi akan meningkatkan kecenderungan untuk mengurangi kelompok miskin, bukan hanya ribuan masyarakat yang mampu untuk mempertahankan hidupnya, tetapi juga mereka akan memulai proses pembangunan ekonominya, bahkan investasi pada tiga sector ini akan memutuskan mata rantai perangkap kemiskinan dan membiarkan mereka untuk memulai bergerak kearah perbaikan dan pertumbuhan pendapatannya. (Zafar, 2010)(Sachs, J\& Yang, 1999) Sedemikan pentingan investasi pada tiga bidang ini bagi perekonomian suatu wilayah, sehingga investasi sudah menjadi suatu keniscayaan untuk keberhasilan pembanguan ekonomi wilayah termasuk pembangunan ekonomi wilayah yang tengah dikembangkan oleh provinsi Sumatera Barat, melalui MP3ESB 2013-2025.

Pengembangan investasi dalam pembangunan wilayah dapat berupa penanaman modal dalam negeri oleh swasta dalam negeri, penanaman modal oleh pemerintah sendiri melalui dana pembangunan (autonomous investment), keduanya disebut penanaman modal dalam negeri (domestic investment). Pada sisi lain, penanaman modal yang berasal dari Negara luar baik melalui pemerintahnya maupun melalui perusahaan swasta asing yang dinamakan foreign direct investment (FDI). FDI dapat diklasifikasikan atas dua tipe yakni: 1). Greenfield investment yaitu investasi untuk membangun fasilitas operasional dasar seperti pabrik, sarana dan prasarana dan infrastruktur dasar, seperti jalan, listrik dan sumber energi. Ini semua disebut dengan pembentukan modal (capital formation). 2). Merger and acquisition investment yaitu keterlibatan perusahaan asing dalam mengakuisisi asset dari perusahaan nasional, sehingga perusahaan nasional memperoleh suntikan dana dari perusahaan asing dalam bentuk kepemilikan sahamnya dan lain sebagainya. Pilihan cara masuknya modal asing ini (FDI) ke suatu wilayah akan menentukan keragaan (performance) ekonomi wilayah tersebut, seperti FDI dalam bentuk penelitian dan pengembangan (R\&D), lokalisasi supply, sumberdaya manusia (human resources), dan transfer tekhnologi. Beberapa studi empiris menyatakan bahwa FDI yang jenis Greenfield ternyata memiliki dampak 
yang luas bagi peningkatan kesejahteraan wilayah tempat penanaman modal asing ini, peningkatan kesejahteraan ini melalui pembentukan capital dan produktifitas.

Wilayah pembangunan yang mampu menarik investasi yang lebih banyak adalah wilayah pembangunan yang memiliki kejelasan sistem hakhak kepemilikan (strong property rightprotection), kebijakan ekonomi makro yang stabil, kecukupan infrastruktur dasar seperti sumber energy, kecukupan aksesibilitas, dan sistem perundang udangan yang memfasilitasi terjadinya lingkungan persaingan yang sehat, sehingga melahirkan kualitas yang lebih baik. Sedangkan menurut Could, D.M, et al (Gould \& Emamgholi, 2013:19)factor yang yang menetukan masuknya investasi luar negeri ke suatu negara adalah ditentukan oleh factor ekonomi itu sendiri, factor kelembagaan, geografi dan factor karakteristik kebijakan. Factor kunci yang mempengaruhi investor asing untuk berinvestasi di suatu wilayah adalah ketersediaan sumber energy, tingkat perdagangan yang meminimalisir hambatan-hambatan ekonomi (level of trade barrier), dan kapasitas kelembagaan, seperti pemberantasan korupsi (control of corruption), karena investasi dari FDI ini cenderung mendorong maraknya terjadi korupsi dikalangan para pengambil keputusan investasinya. Sehingga pertumbuhan investasi yang masuk ke suatu wilayah ditentukan oleh factor yang menentukan pertumbuhan FDI seperti ketersediaan sumberdaya alam, ketersediaan sumberdaya manusia, besarnya pajak perusahaan, ketersediaan energy, perkembangan finansial, infrastruktur, stabilitas makro ekonomi, hambatan perdagangan, keterbukaan kebijakan public, dan control terhadap korupsi. Pembangunan ekonomi berbasis kepada zona ekonomi seperti terbentuknya koridor ekonomi; sebagai area demarkasi geografis dalam suatu wilayah dimana aturan bisnis ekonomi berbeda dari yang lainnya(Farole, 2010:2), dalam rencana percepatan dan perluasan pembangunan ekonomi Sumatera Barat ini. zona ekonomi atau koridor ekonomi dibentuk sebagai alat untuk memperlancar perdagangan antar wilayah dan perdagangan regional, investasi, dan kebijakan industry spatial, bertujuan untuk mengatasi hambatan terhadap halangan pada masuknya investasi dalam kegiatan ekonomi yang lebih luas, termasuk hambatan kebijakan, minimnya pengaturan, ketidakmemadainya infrastruktur, bahkan masalah akses terhadap lahan untuk kepentingan pembangunan khususnya pembebasan lahan untuk kepentingan pembangunan. Sehingga dapat dikatakan bahwa zona ekonomi atau koridor ekonomi paling tidak dapat memperoleh tiga keuntungan terhadap wilayah pembangunan yakni: 1). Efisiensi dalam lingkungan kepabeanan/cukai seperti impor barang-barang input industry, 2). Infrastruktur yang lebih mudah diakses dan dipercaya, 3). Insentif fiscal termasuk pembebasan dan pengurangan pajak perusahaan ekspor dan sejalan dengan perbaikan lingkungan administrasi perpajakan itu sendiri.

Penetapan zona ekonomi telah lama memainkan peranan dalam mendorong kegiatan ekonomi lebih 
cepat termasuk mempercepat perdagangan regional. Menurut pemikiran para ekonomi terdahulu zona ekonomi telah berhasil dalam mendorong peningkatan ekspor dan kesempatan kerja. Namun demikian masih ada para ahli ekonomi saat ini yang memandang bahwa zona ekonomi sebagai "second best" solusi alternative untuk menghadapi persaingan, keberhasilan yang dimiliki hanya terbatas pada kondisi khusus tertentu.(Lihat Andriamananjara, 1999). Walaupun demikian, hampir semua sepakat bahwa pembangunan yang berbasis kepada pengembangan zona ekonomi dilakukan dalam rangka untuk memperluas dukungan, daya tarik investasi, menciptakan peluang pekerjaan dan manfaat dari transfer keahlian dan tekhnologi.

Faktor yang berkontribusi terhadap kegagalan pembangunan ekonomi berbasis zona ekonomi ini adalah ketidak cukupan ketersediaan energy listrik, dan sumberday air, birokrasi yang panjang (heavy bureaucracy), ketidak efisienan dan kebiasaan korupsi di sector public. Semuanya telah menghambat masuknya investasi dari eksternal wilayah ke suatu wilayah pembangunan.

Apabila dilihat pada kenyataan empiris, masuknya investasi asing (FDI) ke wilayah Indonesia selama ini di dominasi oleh sector tersier. Pada tahun 2010 tercatat jumlah proyek PMA pada sector tersier ini adalah sebanyak 3076 proyek dengan nilai investasi sebesar 16.214,8 juta US\$, sebanyak $1557(50,62 \%)$ proyek pada sector tersier dengan nilai investasi sebesar 9843,6 juta US\$(60,71\%), sebanyak $1091(35,47 \%)$ proyek pada sector sekunder dengan nilai investasi sebesar 3337,3 juta US\$ (20,58\%). Sedangkan jumlah proyek PMA pada sector primer yang masuk ke Indonesia adalah berjumlah 428 proyek $(13,91 \%)$ dengan nilai investasi sebesar 3033,9 juta US\$ $(18,71 \%)$. Data PMA tahun 2010 ini memperlihatkan bahwa investasi asing melalui FDI didominasi oleh sector tersier yang mencapai lebih dari 50, 62\% , disusul oleh sector sekunder yang mencapai $35,47 \%$, dan sector primer mencapai $13,91 \%$. Diantara sector tersier tersebut yang paling dominan adalah investasi pada sector perdagangan, jasa, hotel dan restoran, sedangkan investasi pada infrastruktur relative kecil hanya 65 proyek $(4,17 \%)$ dari total proyek pada sector tersier tersebut. Pada sector sekunder didominasi oleh jenis proyek industry logam dan mesin, industry makanan, industry kimia, dan industry tekstil. Sedangkan pada sector primer didominasi oleh proyek pertambangan dan tanaman pangan\& perkebunan. Untuk lebih detilnya perkembangan penanaman modal asing ini di Indonesia terutama pada koridor ekonomi Sumatera dapat dilihat pada tabel di bawah ini.

Tabel 2.1.3.1. di bawah memperlihatkan bahwa pada tahun 2013 jumlah proyek investasi PMA di Indonesia adalah sebanyak 9612 proyek dengan nilai investasi sebesar 28617,5 juta US\$. Jumlah investasi PMA yang paling besar itu di koridor ekonomi Sumatera terdapat pada Sumatera Utara sebanyak 347 proyek $(29,38 \%)$ tetapi nilainya hanya 887,5 juta US $\$(26,14 \%)$ dibandingkan dengan Riau yang besarnya investasi PMA sebanyak 168 proyek $(14,22 \%)$ dengan nilai investasi sebesar 1304,9 
juta US\$ $(38,43 \%)$. Zona ekonomi Sumatera Barat sendiri sudah mengalami peningkatan di bandingkan dengan tahun 2010 lalu, dimana jumlah proyek investasi adalah sebanyak 94 proyek $(7,96 \%)$ dengan nilai investasi sebesar 91,4 juta US\$ $(2,69 \%)$.

Tabel 2.1.3.1. Tabel Perkembangan PMA pada Wilayah Koridor Ekonomi Sumatera Tahun 2010 -2013 (Dalam Juta US\$)

\begin{tabular}{|c|c|c|c|c|c|c|c|c|c|}
\hline \multirow[t]{2}{*}{ No } & \multirow[t]{2}{*}{ Provinsi } & \multicolumn{2}{|c|}{2010} & \multicolumn{2}{|c|}{2011} & \multicolumn{2}{|c|}{2012} & \multicolumn{2}{|c|}{2013} \\
\hline & & $P$ & 1 & $P$ & 1 & $P$ & 1 & $P$ & 1 \\
\hline 1. & Aceh & 13 & 4.6 & 40 & 22.5 & 26 & 172.3 & 87 & 94.2 \\
\hline 2. & Sumut & 78 & 181.1 & 115 & 753.7 & 133 & 645.3 & 347 & 887.5 \\
\hline 2. & Sumbar & 10 & 7.9 & 43 & 22.9 & 45 & 75.0 & 94 & 91.4 \\
\hline 3. & Riau & 45 & 86.6 & 64 & 212.3 & 81 & $1,152.9$ & 168 & $1,304.9$ \\
\hline 5. & Jambi & 12 & 37.2 & 31 & 19.5 & 30 & 156.3 & 61 & 34.3 \\
\hline 6. & Sumsel & 51 & 186.3 & 99 & 557.3 & 107 & 786.4 & 142 & 485.9 \\
\hline 7. & Bengkulu & 11 & 25.1 & 18 & 43.1 & 21 & 30.4 & 27 & 22.3 \\
\hline 8. & Lampung & 31 & 30.7 & 54 & 79.5 & 57 & 114.3 & 50 & 46.8 \\
\hline 9. & Babel & 22 & 22.0 & 48 & 146.0 & 30 & 59.2 & 50 & 112.4 \\
\hline 10 & Kepri & 86 & 165.7 & 155 & 219.7 & 165 & 537.1 & 155 & 315.7 \\
\hline 11. & Sumatera & 359 & 747.1 & 667 & $2,076.6$ & 695 & $3,729.3$ & 1,181 & $3,395.3$ \\
\hline 12. & Nasional & 3,076 & $16,214.8$ & 4,342 & $19,474.5$ & 4,579 & $24,564.7$ & 9,612 & $28,617.5$ \\
\hline \multirow[t]{2}{*}{13.} & \% Sumbar & & & & & & & & \\
\hline & $\begin{array}{l}\text { Terhadap } \\
\text { Sumatera }\end{array}$ & 2,79 & 1,06 & 6,45 & 1,10 & 6,47 & 2,01 & 7,96 & 2,69 \\
\hline \multirow[t]{2}{*}{14.} & \% Sumatera & & & & & & & & \\
\hline & $\begin{array}{l}\text { Terhadap } \\
\text { Nasional }\end{array}$ & 11,67 & 4,61 & 15,36 & 10,66 & 15,18 & 15,18 & 12,29 & 11,86 \\
\hline
\end{tabular}

Sumber: www.bkpm.go.id/diakses 14 Agust 2014 Apabila dilihat per sektor pada tahun 2013 ini investasi PMA masih didominasi oleh sector tersier yang mencapai 4823 proyek $(50,18 \%)$ dengan jumlah investasi sebesar 6286,9 juta US\$(21,97\%). Disusul oleh sector sekunder sebanyak 3322 proyek $(34,56 \%)$ dengan nilai investasi sebesar 15858,8 juta US\$ $(55,42 \%)$ dan sector primer terdiri dari 1467 proyek $(15,26 \%)$ dengan nilai investasi sebesar 6417,8 juta US\$(22,61\%). Diantara sector tersier yang paling dominan itu adalah perdagangan, energy listrik, transportasi \& komunikasi. Pada sector sekunder didominasi oleh industry kendaraan, logam, makanan, dan industry farmasi. Sedangkan pada zona ekonomi Sumatera Barat sendiri investasi PMA yang dominan itu adalah pada sector primer dan tersier terutama pertambangan dan perdagangan, untuk investasi pada infrastuktur wilayah kecil.

Pada gambar 2.1.3.1 di bawah terlihat bahwa jumlah proyek PMA yang paling besar itu terdapat pada provinsi Bangka Belitung berjumlah sebanyak 347 proyek dengan nilai sebesar 887,5 juta US\$. Sedangkan untuk PMDN paling besar pada provinsi Bangka Belitung berjumlah 147 proyek dengan nilai sebesar $\mathrm{Rp}$ 5068,9 Milyar. Pada provinsi Sumatera Barat terdapat 50 proyek PMA dan 35 Proyek PMDN dengan nilai paling tinggi pada investasi PMDN sebesar Rp 677,8 milyar, didominsi oleh investasi pada sector pertambangan dan pengalian serta perdagangan. 


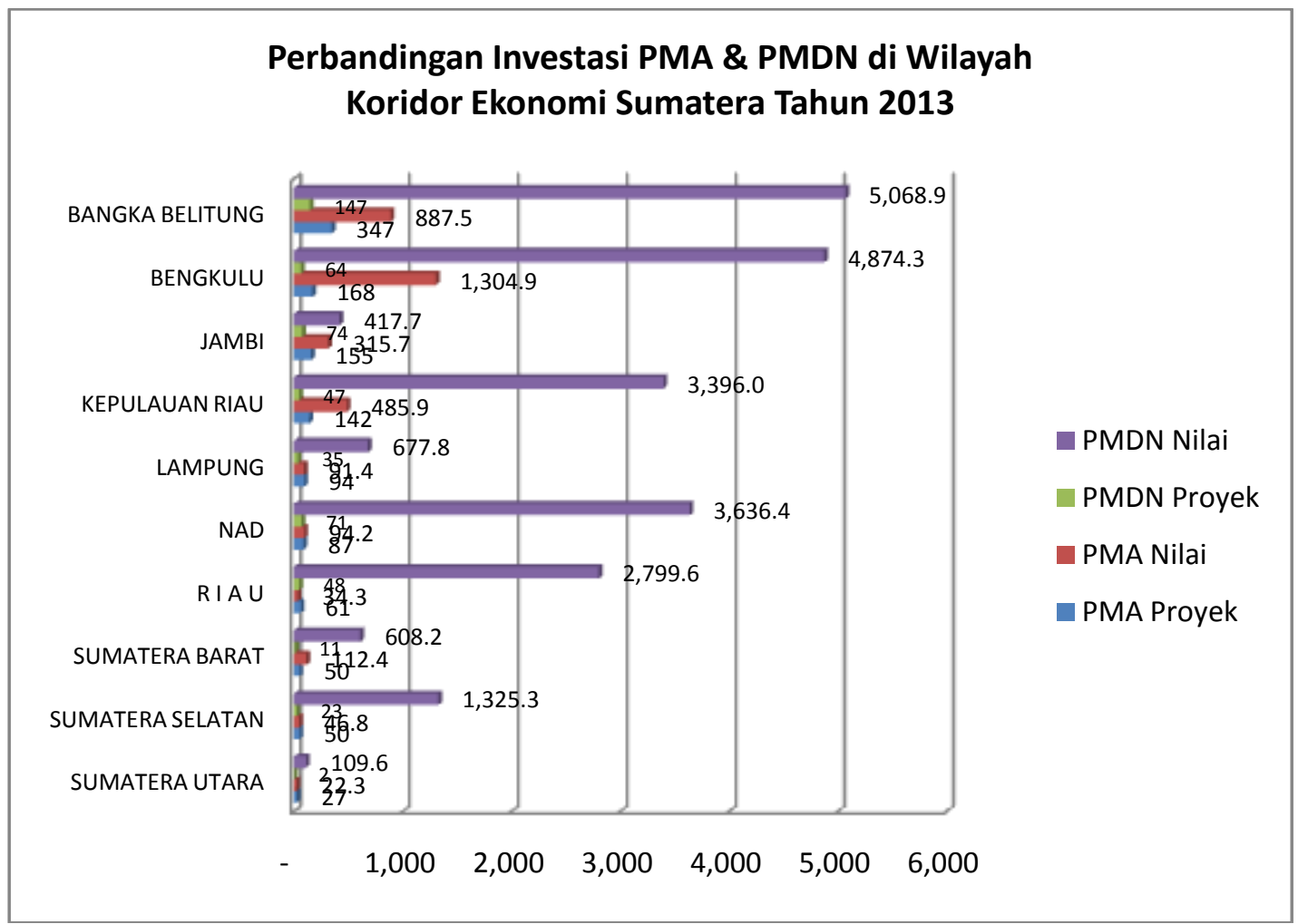

Gambar 2.1.3.1. Perbandingan Investasi PMA dan PMDN di Wilayah Koridor Ekonomi Sumatera Tahun 2013

Tabel 2.1.3.2. di bawah memberikan informasi bahwa pada tahun 2010 jumlah proyek PMDN sebanyak 875 proyek dengan nilai investasi sebesar Rp 60.626,3 milyar, sebanyak 222 proyek $(25,37 \%)$ berada pada wilayah koridor ekonomi Sumatera dengan nilai mencapai $\mathrm{Rp}$ $4.224,2$ milyar $(6,97 \%)$, mengalami kenaikan di tahun 2013 dengan jumlah proyek sebesar 522 (24,52\%) dengan nilai investasi sebesar Rp 22.913,8 milyar (17,88\%). Jika pada MP3EI koridor ekonomi Sumatera ini merupakan pusat pengembangan perkebunan dan lumbung energy Nasional, maka sector investasi masih besar pada sector tersier seperti perdagangan dan industry pengolahan, untuk infrastruktur ekonomi pada koridor ekonomi Sumatera masih rendah. Terlebih lagi pada sector primer seperti tanaman pangan dan perkebunan serta industry pengolahan investasi dari PMA dan PMDN masih relative rendah. Oleh karena itu dalam pengembangan kegiatan ekonomi pada koridor ekonomi Sumatera ini, maka pengembangan sector primer sebagai basis bagi pembangunan ekonomi rakyat harus menjadi prioritas lebih dahulu.

Pada zona ekonomi provinsi Sumatera Barat pada tahun 2010 jumlah proyek PMDN adalah sebanyak 11 proyek $(4,95 \%)$ dengan nilai investasi sebesar Rp 73,8 milyar $(1,75 \%)$ dari total nilai investasi pada wilayah koridor ekonomi Sumatera. Pada tahun 2013 jumlah proyek 
meningkat menjadi 35 proyek $(6,70 \%)$ dengan nilai investasi sebesar $\mathrm{Rp}$ 677,8 milyar $(2,96 \%)$. Perkembangan masuknya investasi dalam negeri ke wilayah provinsi Sumatera Barat masih relative kecil jika dibandingkan dengan wilayah provinsi lain di wilayah koridor ekonomi Sumatera.

Tabel 2.1.3.2. Tabel Perkembangan PMDN pada Wilayah Koridor Ekonomi Sumatera Tahun 2010- 2013 (Rp Milyar)

\begin{tabular}{|c|c|c|c|c|c|c|c|c|c|}
\hline \multirow{2}{*}{ No } & \multirow{2}{*}{ Provinsi } & \multicolumn{2}{|c|}{2010} & \multicolumn{2}{|c|}{2011} & \multicolumn{2}{|c|}{2012} & \multicolumn{2}{|c|}{2013} \\
\hline & & $\mathrm{P}$ & 1 & $P$ & 1 & $P$ & 1 & $\mathrm{P}$ & 1 \\
\hline 1. & Aceh & 5 & 40.9 & 16 & 259.4 & 11 & 60.2 & 71 & $3,636.4$ \\
\hline 2. & Sumut & 41 & 662.7 & 79 & $1,673.0$ & 61 & $2,550.3$ & 147 & $5,068.9$ \\
\hline 4. & Sumbar & 11 & 73.8 & 24 & $1,026.2$ & 22 & 885.3 & 35 & 677.8 \\
\hline 5. & Riau & 52 & $1,037.1$ & 56 & $7,462.6$ & 51 & $5,450.4$ & 64 & $4,874.3$ \\
\hline 5. & Jambi & 17 & 223.3 & 30 & $2,134.9$ & 24 & $1,445.7$ & 48 & 2,799.6 \\
\hline 6. & Sumsel & 29 & $1,738.4$ & 48 & $1,068.9$ & 32 & $2,930.6$ & 47 & $3,396.0$ \\
\hline 7. & Bengkulu & 2 & 8.5 & 2 & - & 1 & 52.6 & 2 & 109.6 \\
\hline 8. & Lampung & 32 & 272.3 & 58 & 824.4 & 48 & 304.2 & 23 & $1,325.3$ \\
\hline 9. & Babel & 5 & 0.4 & 7 & 514.4 & 4 & 533.5 & 11 & 608.2 \\
\hline 10 & Kepri & 28 & 166.9 & 50 & $1,370.4$ & 33 & 43.5 & 74 & 417.7 \\
\hline 11. & Sumatera & 222 & $4,224.2$ & 370 & $16,334.3$ & 287 & $14,256.2$ & 522 & $22,913.8$ \\
\hline 12. & Nasional & 875 & $60,626.3$ & 1,313 & $76,000.7$ & 1,210 & $92,182.0$ & 2,129 & $128,150.6$ \\
\hline \multirow[t]{2}{*}{13.} & \% Sumbar & & & & & & & & \\
\hline & $\begin{array}{l}\text { Terhadap } \\
\text { Sumatera }\end{array}$ & 4,95 & 1,75 & 6,49 & 6,28 & 7,67 & 6,21 & 6,70 & 2,96 \\
\hline \multirow[t]{2}{*}{14.} & \% Sumatera & & & & & & & & \\
\hline & $\begin{array}{l}\text { Terhadap } \\
\text { Nasional }\end{array}$ & 25,37 & 6,97 & 28,18 & 21,49 & 23,72 & 15,47 & 24,52 & 17,88 \\
\hline
\end{tabular}


Hal ini disebabkan karena masih dominannya sector tersier dalam berinvestasi, yang membutuhkan kecukupan sumberdaya dan infrastruktur yang baik. Jika arah investasi selama ini hanya pada sector tersier, tentunya menguntungkan daerah yang sudah memiliki kecukupan infrastruktur dasar seperti energy listrik. Sumberdaya air dan jalan raya, sedangkan wilayah Sumatera Barat masih membutuhkan investasi pada sector primer dan sekunder yang membutuhkan investasi pada infrastruktrur energy seperti listrik dan sumberdaya air, bahkan parasarana dan sarana transportasi seperti jalan raya (high ways) antar provinsi di koridor ekonomi Sumatera.

Apabila merujuk kepada apa yang dikatakan Sachs, J (2010:2) di atas, pengembangan investasi pada wilayah pembangunan yang berdampak kepada peningkatan kualitas hidup masyarakat, mengurangi kelompok miskin dan memperbaiki dan menumbuhkan peningkatan pendapatan rumahtangga, maka pengembangan investasi harus diarahkan kepada investasi pada sector pertanian, infrastruktur dasar, kesehatan dan pendidikan. Konsep zona pembangunan ekonomi melalui pengembangan koridor ekonomi sejalan dengan pemikiran ini, bahwa dimulai dengan pengembangan komoditi utama yang selama ini mendorong pendapatan rumahtangga masyarakat, dilanjutkan dengan pengembangan infrastruktur dasar melalui pengembangan sistem logisitik daerah dan sistem trasportasi daerah, kemudian dilanjutkan dengan pengembangan peningkatan sistem inovasi daerah melalui peningkatan nilai tambah produk utama yang dihasilkan pada koridor ekonomi tersebut, semuanya pada zona ekonomi tertentu yang disebut zona prosesing eksport, (Madani, 2012) dan (Varela, Aldaz-Carroll, \& Iacovone, 2012).

\section{Pengembangan Industri, Jasa dan Pertambangan}

Pengembangan koridor ekonomi melalui pengembangan komoditi utama dalam koridor ekonomi yang telah ditentukan, sesuai dengan potensi ekonomi yang dimiliki oleh rumahtangga masyarakat yang ada dalam satuan koridor ekonomi, tentunya haruslah mengarah kepada peningkatan nilai tambah komoditi utama ini, baik pertambahan nilai karena pertambangan kuantitas, maupun pertambahan nilai karena perubahan bentuk produk komoditi utama tersebut dengan mengembangkan teknologi pengolahan menjadi barang yang memiliki nilai jual yang lebih tinggi. Lihat (Zeng, 2011).

Terdapat 3 (Tiga) sector ekonomi utama dengan komoditi utama yang menjadi pendorong dan penarik pertumbuhan ekonomi di wilayah koridor ekonomi yaitu:

1) Produksi Pertanian dalam arti luas seperti karet, kelapa sawit, kakao,

2) Produksi industry, jasa dan pertambangan seperti industry kimia dan bahan bangungan, industry semen, industry makanan ringan, industry pengolahan gambir, karet, sawit, industry kerajinan, industry tenun, industry sandang dan kulit, industry pakan ternak dan industry lainnya yang memberikan nilai tambah tinggi terhadap produk pertanian dalam arti luas.

3) Kegiatan Pariwisata Alam, Budaya, dan MICE

Ketiga sector ekonomi utama dengan komoditi utama pada ini, agar mampu mempercepat perluasan dan pertumbuhan ekonomi pada wilayah koridor ekonomi, maka dapat dikembangkan melalui pengembangan empat aspek yakni:

1) Pengembangan infrastruktur dasar, maupun infrastruktur social ekonomi

2) Pengembangan Sumberdaya manusia dan sistem inovasi daerah yang mendukung kepada peningkatan nilai tambah komoditi utama

3) Pengembangan Investasi baik investasi yang berasal dari PMDN maupun yang berasal dari PMA 
4) Pengembangan kelembagaan baik untuk kelembagaan pasar input dan produk maupun kelembagaan financial yang mempermudah masuknya investasi ke koridor ekonomi ini.

Pada koridor ekonomi Gerbang Timur dengan jalur koridor ekonomi adalah Padang-PadangpanjangBukittinggi-Batusangkar-Payakumbuh-

Lima Puluh Kota-Pasaman dengan tema pembangunannya adalah pusat produksi industry dan jasa, pintu gerbang perdagangan dan wisata alam dan MICE. Kegiatan utama ekonominya adalah pengembangan dan pengolahan hasil perkebunan: industry gambir, karet, coklat, industry kimia dan bangunan, industry perternakan melalui pengolahan daging dan telur, serta pengembangan wisata alam dan MICE. Maka pengembangan produk industry dan jasa tentunya difokuskan kepada kegiatan ekonomi utama ini yang dijadikan sebagai penarik dan pemicu terjadinya peningkatan kegiatan ekonomi lainnya di dalam koridor ekonomi ini.

Rencana pengembangan Industry, Jasa, dan Pertambangan pada koridor ekonomi Gerbang Timur adalah:

1. Kegiatan peningkatan komoditi utama adalah:

a. Dukungan dan fasilitasi pembangunan kawasan industri kimia dan bangunan di Kota Padang

b. Dukungan dan fasilitasi pembangunan kawasan industri gambir di Kabupaten Lima Puluh Kota oleh pihak pemerintah daerah dan swasta

c. Dukungan dan fasilitasi pembangunan kawasan industri kerajinan di Kota Bukittinggi

d. Dukungan dan fasilitasi pembangunan kawasan industri pangan di Kota Batusangkar

e. Dukungan dan fasilitasi pembangunan kawasan industri pertambangan di Lubuk Sikaping.

f. Dukungan dan fasilitasi pembangunan kawasan industri sandang dan kulit di Kota Padang Panjang

g. Dukungan dan fasilitasi pembangunan kawasan industri pakan ternak
2. Kegiatan Utama Peningkatan Konektifitas Intra dan Antar Koridor adalah

a. Dukungan dan fasilitasi pembangunan jalan tol Padang-BukittinggiPayakumbuh-Batas Riau dengan memanfaatkan investasi swasta melalui pola Publik-Private Partnership;

b. Peningkatan kelas jalan intra dan inter koridor I

c. Peningkatan jalan dan jembatan intra dan inter koridor I

d. Peningkatan terminal angkutan barang dan penumpang pada pusat -pusat pertumbuhan pada koridor I

e. Pembangunan jaringan rel kereta api intra dan inter koridor I

f. Peningkatan kapasitas Pelabuhan Bungus

g. Peningkatan sarana dan prasarana bandara BIM, seperti perluasan dan perpanjang landasan pacu, fasilitas terminal penumpang serta fasilitas kargo Bandara Udara Minangkabau untuk melayani penerbangan domestik dan internasional;

h. Perluasan dan pengembangan dermaga, galangan kapal dan fasilitas lainnya padapelabuhan Teluk Bayur sebagai pelabuhan samudera untuk menampung kapal-kapal ukuran besar untuk meningkatkan kelancaran konektifitas antara Kota Padang dengan kota lainnya yang terkait;

i. Revitalisasi kawasan Industri Padang Industrial Park (PIP) melalui perbaikan manajemen pengelolaan kawasan dan pengembangan prasarana dan fasilitas dalam kawasan

j. Pembangunan fasilitas pengelolaan limbah industri di kawasan industri kimia dan bangunan di Kota Padang dan di kawasan industri gambir di Kabupaten Lima Puluh Kota

$k$. Pembangunan fasilitas pengelolaan limbah industri kerajinan di Kota Bukittinggi, industri pangan di Batusangkar, industri pertambangan di Lubuk Sikaping, dan industri pakan ternak di Kabupaten Lima Puluh Kota. 
l. Fasilitasi pembangunan sumber energi listrik pada kawasan industri di Koridor I, seperti Pembangunan PLTU Bungus untuk menambah kapasitas listrik terpasang guna memenuhi kebutuhan tenaga listrik Kota Padang dan sekitarnya;

$m$. Fasilitasi pembangunan sumberdaya air pada kawasan industri di koridor I

n. Fasilitasi pembangunan sarana dan prasarana telekomunikasi pada kawasan industri di koridorkhsusnya jaring telepon untuk Kota Padang, Kota Bukittinggi, Kota Payakumbuh dan sekitarnya;

o. Fasilitasi pembangunan perumahan pada kawasan industri di koridor I

p. Pengembangan dan peningkatan kapasitas air minum PDAM Padang, Bukittinggi dan Payakumbuh untuk melayani kebutuhan industri dan masyarakat secara keseluruhan;

q. Pendirian Science and Technological Park di kampus Universitas Andalas untuk mendorong pengembangan teknologi dan inovasi serta penciptaan produk-produk baru bernilai ekonomi tinggi;

r. Peningkatan kualitas objek wisata baik yang terdapat pada kota Bukittinggi dan Kota Payakumbuh berikut fasilitas perhotelan;

3. Kegiatan Utama Peningkatan SDM dan IPTEK Pendukung Pusat pusat pertumbuhan, dalah:

a. Dukungan dan fasilitasi pembangunan SMK pada kawasan industri di koridor I

b. Dukungan dan fasilitasi pembangunan pusat pelatihan dan penelitian gambir di koridor I

c. Dukungan dan fasilitasi pembangunan pusat pelatihan dan penelitian pertambangan pada koridor I

d. Dukungan dan fasilitasi pembangunan pusat pelatihan dan penelitian industri kimia dan bangunan di koridor I

e. Dukungan dan fasilitasi pembangunan pusat pelatihan dan penelitian industri pangan di Koridor I f. Dukungan dan fasilitasi pembangunan pusat pelatihan dan penelitian industri pariwisata di koridor I

g. Dukungan dan fasilitasi pembangunan pusat pelatihan dan penelitian industri kerajinan di koridor I

h. Dukungan dan fasilitasi pembangunan pusat pelatihan dan penelitian industri pakan ternak di koridor I

Sedangkan rencana pengembangan Industry, Jasa, dan Pertambangan pada koridor ekonomi Lintas Sumatera adalah:

1. Kegiatan Peningkatan Komoditi Utama

a. Fasilitasi dan dukungan pembangunan industri pengolahan sawit di Koridor II

b. Fasilitasi dan dukungan pembangunan industri pengolahan karet di Koridor II

c. Fasilitasi dan dukungan pembangunan industri pertambangan emas di Koridor II

d. Fasilitasi dan dukungan pembangunan industri pertambangan batu bara di Koridor II

e. Fasilitasi dan dukungan pembangunan industri pertambangan biji besi di Koridor II

f. Fasilitasi dan dukungan pembangunan industri pariwisata budaya di koridor II

2. Kegiatan Peningkatan Konektifitas intra dan antar koridor

a. Peningkatan kelas jalan intra dan inter koridor II

b. Pelebaran jalan intra dan inter koridor II

c. Peningkatan jalan dan jembatan intra dan inter koridor II

d. Peningkatan terminal angkutan barang pada pusat - pusat pertumbuhan pada koridor II

e. Peningkatan terminal angkutan penumpang pada pusat-pusat pertumbuhan pada koridor II

f. Pembangunan jaringan rel kereta api intra dan inter koridor II

g. Pembangunan lapangan terbang perintis pada koridor II 
3. Kegiatan Peningkatan SDM dan IPTEK pendukung pusat pertumbuhan

a. Dukungan dan fasilitasi pembangunan SMK pada kawasan pertanian dan perkebunan di koridor II

b. Dukungan dan fasilitasi pembangunan pusat pelatihan dan penelitian sawit di koridor II

c. Dukungan dan fasilitasi pembangunan pusat pelatihan dan penelitian karet di koridor II

d. Dukungan dan fasilitasi pembangunan pusat pelatihan dan penelitian pertambangan di koridor II

e. Dukungan dan fasilitasi pembangunan pusat pelatihan dan penelitian pertambangan emas, batu bara, dan biji besi di koridor II.

Sedangkan rencana pengembangan Industry, Jasa, dan Pertambangan pada koridor ekonomi Pantai Barat adalah:

1 Kegiatan Peningkatan Komoditi Utama

a. Peningkatan produksi industri pariwisata pantai

b. Fasilitasi dan pengembangan industri pengolahan kakao di Padang Pariaman dan industri pengolahan Sawit di Pasaman Barat, Agam dan Pesisir Selatan.

c. Fasilitasi dan pengembangan industri pengolahan perikanan tangkap dan pengalengan ikan di Pasaman Barat.

d. Pengembangan Pusat Perikanan Laut Bungus yang dilengkapi dengan fasilitas pelabuhan perikanan, cool storage dan industri pengalengan ikan.

e. Fasilitasi dan pengembangan industri pengolahan perikanan budidaya

f. Fasilitasi dan pengembangan industri wisata bahari

g. Peningkatan produksi perikanan tangkap di kepulauan Mentawai.

2 Kegiatan Peningkatan Konektifitas intra dan antar koridor

a. Peningkatan kelas jalan intra dan inter koridor III

b. Pelebaran jalan intra dan inter koridor III, terutamaPerluasan dan peningkatan kualitas jalan raya
Padang-Pariaman-Simpang Empat-Air

Bangis; Perluasan dan peningkatan kualitas jalan raya Simpang EmpatLubuk Sikaping;

c. Peningkatan jalan dan jembatan intra dan inter koridor III

d. Peningkatan terminal angkutan barang pada pusat-pusat pertumbuhan pada koridor III

e. Peningkatan terminal angkutan penumpang pada pusat-pusat pertumbuhan pada koridor III

f. Perluasan jaringan telekomunikasi kota Pariaman dan Simpang Empat;

g. Pembangunan jaringan rel kereta api intra dan inter koridor III

h. Pembangunan lapangan terbang perintis pada koridor III

i. Peningkatan kapasitas dermaga pelabuhan pada koridor IIIterutama Perluasan dan peningkatan kualitas pelabuhan laut Air Bangis;

j. Peningkatan kapasitas penyeberangan laut pada koridor III

k. Peningkatan sarana dan prasarana pelabuhan dermaga pada koridor III

1. Pembangunan pelabuhan pada koridor III untuk mendukung pelabuhan utama Teluk Bayur

m. Pembangunan bandara perintis pada Kabupaten Pasaman Barat di koridor III

n. Pembangunan bandara domestic pada Tua Pejat di Kabupaten Kepulauan Mentawai

3 Kegiatan Peningkatan SDM dan IPTEK pendukung pusat pertumbuhan

a. Dukungan dan fasilitasi pembangunan SMK pada kawasan perikanan tangkap dan budidaya di koridor III.

b. Dukungan dan fasilitasi pembangunan SMK pariwisata di Tua Pejat di koridor III.

c. Dukungan dan fasilitasi pembangunan SMK pada kawasan kakao di koridor III.

d. Dukungan dan fasilitasi pembangunan pusat pelatihan dan penelitian kakao di koridor III. 
e. Dukungan dan fasilitasi pembangunan pusat pelatihan dan penelitian perikanan budidaya di koridor III.

f. Dukungan dan fasilitasi pembangunan pusat pelatihan dan penelitian perikanan tangkap di koridor III.

g. Dukungan dan fasilitasi pembangunan pusat pelatihan dan penelitian wisata pantai di koridor III

Rencana pengembangan industry, jasa dan pertambangan pada koridor ekonomi ini telah diimplementasikan sebagian dalam sejenis proyek pengembangan yang telah dilakukan pada setiap pusat kegiatan ekonomi utama. Proyek pengembangan itu difokuskan kepada pengembangan konektifitas wilayah koridor ekonomi yang meliputi:

1. Pengembangan Pembangunan Bandara

2. Pengembangan pembangunan Pelabuhan/Terminal

3. Pengembangan pembangunan terminal angkutan darat

4. Pengembangan pembangunan kereta api

5. Pengembangan pembangunan jalan

6. Pengembangan pembangunan sumber energy

7. Pengembangan pembangunan SDM IPTEK.

Semua jenis pengembangan di atas ditujukan untuk mempersiapkan terbangunannya konektifitas diantara pusat koridor ekonomi di wilayah Sumatera Barat. Pembangunan konektifitas, merupakan upaya untuk mempersiapkan berkembangnya industry, jasa dan pertambangan di wilayah koridor ekonomi, karena wilayah industry membutuhkan system pentrasportasian bahan baku ke lokasi pusat industry dan produk yang dihasilkan dilokasi pabrik untuk ditransportasikan ke Pasar. Artinya, dalam mengembangkan wilayah industry, diperlukan memperkuat konektifitas diantara wilayah input dan pasar.

\section{Tinjauan Penutup Kearah Kesimpulan}

Pengembangan infrastruktur industry pada koridor ekonomi berkaitan dengan penyediaan infrastruktur dasar bagi kawasan industry, seperti penyediaan sumber energy listrik dengan membangun pembangkit listrik sendiri pada kawasan industry yang akan dibangun, penyediaan tempat pengelolaan limbah (waste treatment plan), pembangunan sumber air bersih dan air bagi kepentingan industry di kawasan Industri ini. Pengembangan koridor ekonomi fokus pada 3 program dan kegiatan, yaitu:

1) Pengembangan komoditi utama produk pertanian

2) pengembangan industri jasa dan pertambangan

3) pengembangan pariwisata

Kendala pengembangan Koridor Ekonomi Sumatera Barat antara lain: peruntukan kawasan pertanian yang belum jelas, pembebasan lahan yang sangat lambat, koordinasi sektoral yang masih lemah, keterpaduan penggunaan infrastruktur yang masih rendah, program dan kegiatan yang ada belum dialokasikan pembiayaannya, belum terbentuknya kelembagaan yang kuat di kawasan industri.

Pengembangan zona ekonomi melalui pengembangan produk pertanian (kelapa sawit, karet, gambir, kakao, kulit, perikanan tangkap dan perikanan budidaya, serta pangan) pada koridor ekonomi ditujukan untuk menunjang pengembangan industri pengolahan hasil pertanian dalam percepatan dan perluasan ekonomi daerah.

Pengembangan Zona Ekonomi melalui pengembangan industri dan jasa dilakukan dengan pengembangan kawasan industri pengolahan pada setiap koridor ekonomi melalui pembentukan kelembagaan yang kuat dengan meningkatkan peran swasta, lihat (Zeng, 2011). Pengembangan pariwisata pada setiap koridor ekonomi untuk percepatan dan perluasan pembangunan ekonomi dilakukan dengan pembangunan infrastruktur dan integrasi layananuntuk 
meningkatkan daya tarik destinasi pariwisata.

Pengembangan SDM untuk percepatan dan perluasan pengembangan ekonomi dilakukan dengan pemahaman dan penerapan standar mutu dan pelayanan yang diinginkan pasar. Sedangkan pengembangan zona ekonomi melalui pengembangan inovasi IPTEKDA diarahkan untuk mendukung kearah peningkatan nilai tambah dan daya saing.

\section{DAFTAR PUSTAKA}

\subsection{2/economica.2016.v4.i2.355}

Andriamananjara, S. (1999). On the Size and Number of Regional Integration Arrangements. Policy Research Working Paper, WPS2117(May).

Bappenas. (2011). Masterplan P3EI Pelaksanaan dan Tata Kelola MP3EI. Perpres No: 32 Tahun 2011.

Farole, T. (2010). Second Best? Investment Climate and Performance in Africa' s Special Economic Zones. Policy Research, (October), 37.

Gould, D. M., \& Emamgholi, A. S. S. (2013). Attracting Foreign Direct Investment What Can South Asia' s Lack of Success Teach Other Developing Countries?, (November). http://doi.org/10.1177/139156141454 8939

Gubernur Provinsi Sumatera Barat. (2013). Masterplan Percepatan dan Perluasan Pembangunan Ekonomi Sumatera Barat Tahun 2013-2025. Pergub No: 73 Tahun 2013, 000.

Madani, D. (2012). A Review of the role and impact of export processing zones. WPS2238, 2238(November), $1-34$.

Sachs, J. D., \& Yang, X. (n.d.). of Monopolistic Competition Working Papers. CID Working Paper, Harvard University, No 14.

Varela, G., Aldaz-Carroll, E., \& Iacovone, L. (2012). Determinants of market integration and price transmission in Indonesia. Policy Research Working Paper Series, (June). http://doi.org/10.1355/ae30-1b

Zafar, A. (2010). Learning from the Chinese Miracle Development Lessons for Sub-Saharan Africa, (February).

Zeng, D. Z. (2011). How Do Special Economic Zones and Industrial Clusters Drive China ' s Rapid Development? World, (March), 1-51. 